\title{
Student Dropout and Graduation in Colombian Economics Programs
}

\author{
María Camila González Gutiérrez ${ }^{1}$, Adriana Carolina Silva Arias ${ }^{2}$, Jaime Andrés Sarmiento Espinel ${ }^{3}$ \\ ${ }^{1}$ Universidad Militar Nueva Granada, Bogotá, Colombia, gesma@unimilitar.edu.co \\ ${ }^{2}$ Universidad Militar Nueva Granada,Bogotá, Colombia, adriana.silva@unimilitar.edu.co \\ ${ }^{3}$ Universidad Militar Nueva Granada,Bogotá, Colombia, jaime.sarmiento@unimilitar.edu.co
}

\begin{abstract}
Dropout and graduation from undergraduate students were associated with the socioeconomic context, academic performance and characteristics of the educational institutions. In this paper, we did a characterization of dropout and graduation of students from programs related to economics in Colombia. We estimated a multinomial logit regression to measure marginal effects from a set of individual, familiar, institutional and context factors on dropout and graduation probabilities of Colombian economics students during the 1998 to 2015 time period.
\end{abstract}

KEYWORDS: Student dropout, graduation, higher education, economics, multinomial logit regression

\section{Introduction}

People who invest in education, especially in tertiary education, have better opportunities to enter the labor market and get more incomes on their work life compared to those who have spent less years in higher education (Aina 2013, Brodaty, Gary-Bobo, and Prieto 2008). Therefore, it is important to analyze the factors associated with the dropout and graduation of undergraduate students.

Student dropout is associated with the student's profile and their socioeconomic conditions, including student performance in the academic program, parents' educational level, admission age, lack of motivation, among others (Patiño and Cardona 2012). These individual factors are related to levels of student's satisfaction with the academic program and perception of institutional support in academic performance (Espíndola and León 2002).

Regarding graduation and successful completion of undergrad studies, the literature suggests good practices of educational institutions such as encouraging communication, cooperation, financial support, active learning and respecting different talents and ways of learning (Carey 2004, Chickering and Gamson 1987). Government financial support for students from low-income families provides higher probabilities to graduate (Chen 2008). The chances that a student graduates is also related to student admission test scores, student financial resources, unemployment rates, institutional mission, institution size and location (Glocker 2011, Chickering and Gamson 1987, Carey 2004, Ober, Beekman, and Pierce 2018).

The study universe was Colombian students who belong to academic programs related to economics between the first semester of 2000 until the second semester of 2015. We used data from SPADIES (Sistema para la Prevención de la Deserción de la Educación Superior). Information contains characteristics of the students and their families, departments and universities.

In this document, we analyzed the factors associated to dropout and graduation of economics students from Colombia. This is relevant, because dropout and graduation of economics students had a high percentage, $43.1 \%$ and $28.3 \%$ respectively for the period 2000 to 2015 in Colombia. We used a multinomial logistic regression in order to estimate the incidence of a set of factors on the probabilities to dropout or graduate.

\section{Literature review}

The dropout concept is understood in this paper as a situation faced by students when they expect to obtain professional training and they do not complete their educational project (Tinto 1982). We understood Graduation as the successful completion of higher education studies, that is, obtaining a degree awarded by the educational institution to complete vocational training.

The dropout of undergrad students is a social problem because it reduces the formation of human capital (Centro de Estudios sobre Desarrollo Económico 2014, De la Fuente 2003, Becker 1962, 1967). Causes of dropout are associated with the intrinsic profile of a student (Otero 1999, Braxton, Shaw 
Sullivan, and Johnson 1997). In specific, the literature mentioned that dropout differs according to gender, levels of student satisfaction, career expectations, perception of institutional support in academic performance, cultural adaptation, social skills, educational quality of institution, students' parents education level and participation in extracurricular activities (Patiño and Cardona 2012, Card 1999).

Dropout is also associated with the socio-economic context of the student as household income, labor status or access to financial support (Abril Valdez et al. 2008, Dickson and Harmon 2011). Also, it is related to the students' academic behavior such as academic performance and failure of subjects (Abril Valdez et al. 2008).

In addition, the decision to dropout is related to context. Dropout arises because of the crisis in educational system and reveals the inefficiency to retain and graduate students. It is also a consequence of poor labor market prospects. Because of high local youth unemployment rates, students lose motivation and reduce their engagement to graduate of higher education leading to dropout student (Osorio, Jaramillo, and Jaramillo 1999, Contini, Cugnata, and Scagni 2016).

On the other hand, the literature mentioned that low graduation rates were due to disadvantages in socioeconomic conditions, parental occupational status and family income (Carpenter, Hayden, and Long 1998). In other studies, the most relevant variable in graduation was academic performance background, while household income was the least relevant (Chen, Chen, and Oztekin 2017, Schofer and Meyer 2005). External factors related to graduation are student admissions processes and employability (Hunsaker and Thomas 2013, Stout et al. 2018, Heck, Lam, and Thomas 2014, Kwiek 2013, Hatos and Saveanu 2016, Hamrick, Schuh, and Shelley 2004).

Sarmiento Espinel and Silva Arias (2014) mentioned the number of graduate students in economics has increased in Colombia since the seventies. However, it showed a decreasing trend in two periods of time, for 1988-1993 and 2002-2007.

Finally, according to Vásquez et al. (2003), the literature about dropout and graduation is scarce for particular cases, specific institutions or academic programs.

\section{Methodology}

In order to explain the distribution of economics students in Colombia, for the period 2000 to 2015 in three possible categories as active, dropout, graduate, we used a multinomial logistic regression model. The active state was used to analyze the risk function to which the student was exposed to move to the status of dropout or graduate. By this way it is possible to estimate the effect of the characteristics of the student, their home and the educational institution. The model is a multivariate analysis of competitive risk context, to derive a discrete time model of multiple results (Arias Ortiz and Dehon 2013):

$h_{i}(k, t)=\frac{\exp \left[\left(\alpha_{k 1} D_{i 1}+\cdots+\alpha_{k T} D_{i T}\right)+\left(\beta_{k 1} X_{1 i t}+\cdots+\beta_{k p} X_{p i t}\right)\right]}{1+\sum_{1}^{K} \exp \left[\left(\alpha_{l_{1}} D_{i 1}+\cdots+\alpha_{l T} D_{i T}\right)+\left(\beta_{l 1} X_{1 i t}+\cdots+\beta_{l p} X_{p i t}\right)\right]}$

Where $X_{p}$ are the explanatory variables. $\beta_{l p}$ are the parameters associated with the variables $p$ and the outcome $l$ (active students). $D_{i T}$ are dummy variables (dropout and graduate students). $T$ is the last period of observed time, that is, semesters.

$\alpha_{k T}$ are the intercepts that capture the base risk level in each semester. $\beta_{k p}$ describes the effects of the factors associated with the risk function of dropping out or graduation. We get the following expression after the logistic transformation:

$$
\log \left[\frac{h_{i}(k, t)}{h_{i}(0, t)}\right]=\left(\alpha_{k 1} D_{i 1}+\cdots+\alpha_{k T} D_{i T}\right)+\left(\beta_{k 1} X_{1 i t}+\cdots+\beta_{k p} X_{p i t}\right)
$$

Where $h_{i}(0, t)$ is the risk of the student to be active. The expression $\frac{h_{i}(k, t)}{h_{i}(0, t)}$ is a measure of the relative risk of occurrence of event $k$ with respect to the risk of non-event. That is, the risk of dropping out or graduating from the risk of being an active student. 


\section{Data}

We used a sample of Colombian economics undergraduate students from SPADIES database. The sample contains students' information since the first semester of 2000 until the second semester of 2015.

There were 75 economics programs in 23 departments of Colombia. There sample contains information of 95,999 Colombian economics students. The composition of student status was $28.6 \%$ active, $43.1 \%$ dropout and $28.3 \%$ successfully complete their studies. Table 1 shows some descriptive statistics of the variables of interest per semester-student.

Table 1. Descriptive statistics of economics students (2000-2015)

\begin{tabular}{|c|c|c|c|c|}
\hline Variable & Total & Active & Dropout & Complete studies \\
\hline \multicolumn{5}{|l|}{ Gender } \\
\hline Male & 0.550 & 0.530 & 0.499 & 0.599 \\
\hline Female & 0.450 & 0.470 & 0.501 & 0.401 \\
\hline Age & 20.638 & 20.655 & 20.652 & 20.620 \\
\hline \multicolumn{5}{|l|}{ Social stratum } \\
\hline 1 & 0.074 & 0.103 & 0.080 & 0.055 \\
\hline 2 & 0.299 & 0.310 & 0.327 & 0.273 \\
\hline 3 & 0.349 & 0.348 & 0.336 & 0.359 \\
\hline 4 & 0.081 & 0.117 & 0.063 & 0.075 \\
\hline 5 & 0.031 & 0.042 & 0.023 & 0.030 \\
\hline 6 & 0.021 & 0.027 & 0.014 & 0.023 \\
\hline $\mathrm{N} / \mathrm{A}$ & 0.145 & 0.054 & 0.157 & 0.185 \\
\hline \multicolumn{5}{|l|}{ Mother's education level } \\
\hline Without education - N/A & 0.025 & 0.015 & 0.025 & 0.030 \\
\hline Primary & 0.138 & 0.132 & 0.160 & 0.125 \\
\hline Secondary & 0.352 & 0.393 & 0.381 & 0.307 \\
\hline Technical/technologist & 0.192 & 0.169 & 0.188 & 0.208 \\
\hline Higher education & 0.293 & 0.291 & 0.246 & 0.330 \\
\hline \multicolumn{5}{|l|}{ Job in high school } \\
\hline No & 0.962 & 0.960 & 0.948 & 0.975 \\
\hline Yes & 0.038 & 0.040 & 0.052 & 0.025 \\
\hline \multirow[t]{2}{*}{ High school exam score } & 74.271 & 74.479 & 68.710 & 78.311 \\
\hline & $(23.273)$ & $(23.898)$ & $(24.585)$ & $(20.964)$ \\
\hline \multirow[t]{2}{*}{ Reprobation rate } & 0.185 & 0.203 & 0.329 & 0.067 \\
\hline & $(0.302)$ & $(0.321)$ & $(0.358)$ & $(0.166)$ \\
\hline \multicolumn{5}{|l|}{ Government educational credit } \\
\hline No & 0.940 & 0.947 & 0.954 & 0.925 \\
\hline Yes & 0.060 & 0.053 & 0.046 & 0.075 \\
\hline \multicolumn{5}{|l|}{ Academic institutional support } \\
\hline No & 0.961 & 0.927 & 0.967 & 0.976 \\
\hline Yes & 0.039 & 0.073 & 0.033 & 0.024 \\
\hline \multicolumn{5}{|l|}{ Financial institutional support } \\
\hline No & 0.870 & 0.859 & 0.892 & 0.859 \\
\hline Yes & 0.130 & 0.141 & 0.108 & 0.141 \\
\hline \multicolumn{5}{|l|}{ Institution type } \\
\hline Sectional & 0.110 & 0.083 & 0.101 & 0.131 \\
\hline Main & 0.890 & 0.917 & 0.899 & 0.869 \\
\hline \multicolumn{5}{|l|}{ Institution sector } \\
\hline Public & 0.281 & 0.314 & 0.289 & 0.257 \\
\hline Private & 0.719 & 0.686 & 0.711 & 0.743 \\
\hline \multicolumn{5}{|l|}{ Institution character } \\
\hline Technical Institute & 0.051 & 0.059 & 0.060 & 0.041 \\
\hline University & 0.949 & 0.941 & 0.940 & 0.959 \\
\hline \multirow[t]{2}{*}{ Institution age } & 53.551 & 53.035 & 52.605 & 54.535 \\
\hline & $(16.030)$ & $(15.843)$ & $(16.260)$ & $(15.901)$ \\
\hline \multicolumn{5}{|l|}{ Quality accredited institution } \\
\hline No & 0.370 & 0.340 & 0.436 & 0.337 \\
\hline Yes & 0.630 & 0.660 & 0.564 & 0.663 \\
\hline \multirow[t]{2}{*}{ Unemployment rate } & 0.109 & 0.092 & 0.112 & 0.116 \\
\hline & $(0.020)$ & $(0.010)$ & $(0.020)$ & $(0.018)$ \\
\hline
\end{tabular}

Source: SPADIES 2000-2015. Authors' calculation. Note: Standard deviations in parentheses 
About the characteristics of those who dropout in terms of semesters-students, $50.1 \%$ were women, with 20.7 years of age on average. In terms of socioeconomic conditions, the majority belonged to social stratum 3 (intermediate). The most frequent mother's education level was secondary school. Regarding high school, most students did not work and they obtained 69/100 points on average in the national exam to higher education entrance. Additionally, the majority of dropout students had no educational credit from the government, nor any kind of support from the educational institution.

In the case of those who complete their economics studies, they present similar characteristics to the students who dropped out. However, mother's education was principally higher education. They obtained $78 / 100$ points on average in the national exam in high school.

\section{Results}

After estimate the competing risk model, Table 2 presents estimated marginal effects of covariates on dropout and complete studies probability.

Table 2. Marginal effects, economics students (2000-2015)

\begin{tabular}{|c|c|c|c|c|}
\hline Variable & Dropo & & Complete & studies \\
\hline Gender (ref. Male) & & & & \\
\hline Female & 0.084 & $* * *$ & -0.094 & $* * *$ \\
\hline & $(0.002)$ & & $(0.001)$ & \\
\hline Age (ref. mean) & -0.013 & $* * *$ & 0.034 & $* * *$ \\
\hline & $(0.001)$ & & $(0.000)$ & \\
\hline Social stratum (ref. Level 1) & & & & \\
\hline 2 & -0.019 & $* * *$ & 0.030 & $* * *$ \\
\hline & $(0.003)$ & & $(0.003)$ & \\
\hline 3 & -0.031 & $* * *$ & 0.042 & $* * *$ \\
\hline & $(0.003)$ & & $(0.003)$ & \\
\hline 4 & -0.027 & $* * *$ & 0.009 & $* *$ \\
\hline & $(0.004)$ & & $(0.004)$ & \\
\hline 5 & -0.004 & & -0.002 & \\
\hline & $(0.005)$ & & $(0.005)$ & \\
\hline 6 & -0.033 & $* * *$ & 0.038 & $* * *$ \\
\hline & $(0.006)$ & & $(0.006)$ & \\
\hline $\mathrm{N} / \mathrm{A}$ & -0.001 & & 0.039 & $* * *$ \\
\hline & $(0.004)$ & & $(0.004)$ & \\
\hline $\begin{array}{l}\text { Mother's education level (ref. Without } \\
\text { education - N/A) }\end{array}$ & & & & \\
\hline Primary & -0.004 & & 0.043 & $* * *$ \\
\hline & $(0.005)$ & & $(0.005)$ & \\
\hline Secondary & 0.010 & $* *$ & 0.024 & $* * *$ \\
\hline & $(0.005)$ & & $(0.005)$ & \\
\hline Technical/technologist & -0.038 & $* * *$ & 0.082 & $* * *$ \\
\hline & $(0.005)$ & & $(0.005)$ & \\
\hline Higher education & -0.056 & $* * *$ & 0.108 & $* * *$ \\
\hline & $(0.005)$ & & $(0.005)$ & \\
\hline Job in high school & 0.110 & $* * *$ & -0.123 & $* * *$ \\
\hline & $(0.004)$ & & $(0.003)$ & \\
\hline High school exam score (ref. mean) & -0.003 & $* * *$ & 0.003 & $* * *$ \\
\hline & $(0.000)$ & & $(0.000)$ & \\
\hline Reprobation rate (ref. mean) & 0.818 & $* * *$ & -0.873 & $* * *$ \\
\hline & $(0.006)$ & & $(0.005)$ & \\
\hline Government educational credit & -0.059 & $* * *$ & 0.059 & $* * *$ \\
\hline & $(0.003)$ & & $(0.003)$ & \\
\hline Academic institutional support & 0.032 & $* * *$ & -0.070 & $* * *$ \\
\hline & $(0.004)$ & & $(0.004)$ & \\
\hline Financial institutional support & -0.050 & $* * *$ & 0.050 & $* * *$ \\
\hline & $(0.002)$ & & $(0.002)$ & \\
\hline Institution type (ref. Main): Sectional & -0.032 & $* * *$ & 0.048 & $* * *$ \\
\hline
\end{tabular}




\begin{tabular}{|c|c|c|c|c|}
\hline & $(0.002)$ & & $(0.002)$ & \\
\hline \multirow[t]{2}{*}{ Institution sector (ref. Private): Public } & -0.012 & $* * *$ & -0.014 & $* * *$ \\
\hline & $(0.002)$ & & $(0.002)$ & \\
\hline \multirow{2}{*}{$\begin{array}{l}\text { Institution character (ref. University): } \\
\text { Technical Institute }\end{array}$} & 0.006 & $*$ & -0.032 & $* * *$ \\
\hline & $(0.003)$ & & $(0.003)$ & \\
\hline \multirow[t]{2}{*}{ Institution age (ref. mean) } & -0.001 & $* * *$ & 0.001 & $* * *$ \\
\hline & $(0.000)$ & & $(0.000)$ & \\
\hline \multirow[t]{2}{*}{ Quality accredited institution } & -0.083 & $* * *$ & 0.027 & $* * *$ \\
\hline & $(0.002)$ & & $(0.002)$ & \\
\hline \multirow[t]{2}{*}{ Unemployment rate (ref. mean) } & 3.996 & $* * *$ & 9.566 & $* * *$ \\
\hline & $(0.236)$ & & $(0.209)$ & \\
\hline
\end{tabular}

Authors' calculation. Note: Standard errors in parentheses. *Significant at $10 \%$ level, ** Significant at 5\% level, *** Significant at $1 \%$ level

Keeping all other variables constant, women had 8.4 percentage points more probability of dropping out and 9.4 percentage points less probability of to graduate than men. If the social stratum increases, in general the student had less percentage points of probability of dropping out and more in probability to graduate than students of stratum 1. If the mother had technical education or higher education, then the student had less percentage points in probability of dropping out and were more likely to graduate than students with mothers without education.

Students' academic performance during their economics program attendance was the most influent factor on the likelihood of dropping out or graduate. An increase on student's reprobation rate causes an increase of 81.8 percentage points on dropout probability and a decrease of 87.3 percentage points in graduate probability.

\section{Conclusions}

According to the literature, there are different factors that could influence a student decision to dropping out or graduate from his or her studies. For Colombian economics undergraduate students, the most influential factor on these two scenarios was their academic performance during their attendance on this education program.

It is important to clarify that this database does not allow to identify the institutional transfers in Colombian educational system over time, which show the migratory movements of the dropout students towards another academic program or another educational institution. For future researches, these cases associated with dropping out from an undergraduate program to start a new one should be studied. These cases could reflect academic freedom, a vocational crisis or a student's adaptability to a higher education context.

\section{Funding}

Product derived from the research project INV-ECO 2581 financed by the Vice Presidency for Research of the Universidad Militar Nueva Granada - 2018 term.

\section{References}

Abril Valdez, Elba, Rosario Román Pérez, Maria José Cubillas Rodríguez, and Icela Moreno Celaya. 2008. "Drop out or selfexclusion? An analysis of drop out causes in Mexico’s Sonoran High School students" (¿ Deserción o autoexclusión? Un análisis de las causas de abandono escolar en estudiantes de educación media superior en Sonora, México). Revista Electrónica de Investigación Educativa 10 (1): 1-16.

Aina, Carmen. 2013. "Parental background and university dropout in Italy." Higher Education 65 (4): $437-456$. Doi: $10.2307 / 23470831$.

Arias Ortiz, Elena, and Catherine Dehon. 2013. "Roads to success in the Belgian French community's higher education system: Predictors of dropout and degree completion at the Université Libre de Bruxelles." Research in Higher Education 54 (6): 693-723. Doi: 10.1007/s11162-013-9290-y.

Becker, Gary Stanley. 1962. "Investment in human capital: A theoretical analysis." Journal of Political Economy 70 (5, Part 2): 9-49. Doi: 10.2307/1829103.

Becker, Gary Stanley. 1967. Human capital and the personal distribution of income: An analytical approach: Institute of Public Administration. 
Braxton, John M, Anna V Shaw Sullivan, and Robert M Johnson. 1997. "Appraising Tinto's theory of college student departure." In Higher Education: Handbook of Theory and Research, edited by J. Smart, 107-164. New York: Agathon.

Brodaty, Thomas, Robert J. Gary-Bobo, and Ana Prieto. 2008. Does speed signal ability? The impact of grade repetitions on employment and wages. CEPR Discussion Papers 6832.

Card, David. 1999. "The causal effect of education on earnings." In Handbook of Labor Economics, 1801-1863. Elsevier.

Carey, Kevin. 2004. A matter of degrees: Improving graduation rates at four-year colleges and universities. Washington, DC: The Education Trust.

Carpenter, Peter G, Martin Hayden, and Michael Long. 1998. "Social and economic influences on graduation rates from higher education in Australia." Higher Education 35 (4): 399-422. Doi: 10.1023/A:1003103011367.

Centro de Estudios sobre Desarrollo Económico (CEDE). 2014. Report of dropout determinants (Informe Determinantes de la deserción).

Chen, Rong. 2008. "Financial aid and student dropout in higher education: A heterogeneous research approach." In Higher Education, edited by John C. Smart, 209-239. Dordrecht: Springer Netherlands.

Chen, Ya, Yao Chen, and Asil Oztekin. 2017. "A hybrid data envelopment analysis approach to analyse college graduation rate at higher education institutions." INFOR: Information Systems and Operational Research 55 (3): 188-210.

Chickering, Arthur W, and Zelda F Gamson. 1987. "Seven principles for good practice in undergraduate education." $A A H E$ bulletin:3-7.

Contini, Dalit, Federica Cugnata, and Andrea Scagni. 2016. "Social selection in higher education. Enrolment, dropout and timely degree attainment in Italy." Higher Education 75 (5): 785-808. Doi: 10.1007/s10734-017-0170-9.

De la Fuente, Ángel. 2003. Human capital and growth in the knowledge economy (Capital humano y crecimiento en la economía del conocimiento). In Estudio 23: Fundación COTEC.

Dickson, Matt, and Colm Harmon. 2011. "Economic returns to education: What we know, what we don't know, and where we are going-some brief pointers." Economics of Education Review 30 (6): 1118-1122. Doi: 10.1016/j.econedurev.2011.08.003.

Espíndola, Ernesto, and Arturo León. 2002. "Dropping out of school in Latin America: A priority issue for the regional agenda (La deserción escolar en América Latina: un tema prioritario para la agenda regional)". Revista Iberoamericana de Educación 30: 39-62.

Glocker, D. 2011. "The effect of student aid on the duration of study." Economics of Education Review 30 (1): 177-190. Doi: 10.1016/j.econedurev.2010.08.005.

Hamrick, Florence A, John H Schuh, and Mack C Shelley. 2004. "Predicting higher education graduation rates from institutional characteristics and resource allocation." Education Policy Analysis Archives 12 (19). Doi: 10.14507/epaa.v12n19.2004.

Hatos, Roxana Elisabeta, and Tomina Gabriela Saveanu. 2016. "Factors influencing the evolution of higher education graduation in Romania: Spotlighting economic studies." Annals of Faculty of Economics 1 (2): 203-213.

Heck, Ronald H, Wendy S Lam, and Scott L Thomas. 2014. "State political culture, higher education spending indicators, and undergraduate graduation outcomes." Educational Policy 28 (1): 3-39. Doi: 10.1177/0895904812453996.

Hunsaker, B Tom, and Douglas E Thomas. 2013. "Graduation rates and the higher education demographic evolution." Journal of Learning in Higher Education 9 (2): 29-33.

Kwiek, Marek. 2013. "From system expansion to system contraction: Access to higher education in Poland." Comparative Education Review 57 (3): 553-576. Doi: 10.1086/670662.

Ober, David R, John A Beekman, and Rebecca L Pierce. 2018. "Analyzing four-year public university and two-year college graduation rates." Journal of Education and Training Studies 6 (4):221-247.

Osorio, Ana, Catalina Jaramillo, and Alberto Jaramillo. 1999. Student dropout of undergraduate programs 1995-1998 EAFIT (Deserción estudiantil en los programas de pregrado 1995-1998 EAFIT).

Otero, Luis. 1999. Dropout: a conceptual and methodological reference for research (Deserción: un referente conceptual y metodológico para su estudio).

Patiño, Luceli, and Angélica María Cardona. 2012. "Review of studies on university dropout in Colombia and Latin America (Revisión de algunos estudios sobre la deserción estudiantil universitaria en Colombia y Latinoamérica)." Theoria 21 (1): 9-20.

Sarmiento Espinel, Jaime Andrés, and Adriana Carolina Silva Arias. 2014. "Education for economist professionals in Colombia (La formación del economista en Colombia)." Revista Facultad de Ciencias Económicas: Investigación y Reflexión 22 (1): 231-262. Doi: 10.18359/rfce.650.

Schofer, Evan, and John W Meyer. 2005. "The worldwide expansion of higher education in the twentieth century." American Sociological Review 70 (6): 898-920. Doi: 10.2307/4145399.

Stout, Rebecca, Cephas Archie, David Cross, and Carol A Carman. 2018. "The relationship between faculty diversity and graduation rates in higher education." Intercultural Education 29 (3): 399-417. Doi: 10.1080/14675986.2018.1437997.

Tinto, Vincent. 1982. "Limits of theory and practice in student attrition." The Journal of Higher Education 53 (6):687-700. Doi: $10.2307 / 1981525$.

Vásquez, Johanna, Elkin Castaño, Santiago Gallón, and Karoll Gómez. 2003. Determinants of dropout at the University of Antioquia (Determinantes de la deserción estudiantil en la Universidad de Antioquia). Borradores del CIE 002303: Centro de Investigaciones Económicas, Universidad de Antioquia. 